\title{
Barriers to Implementation of Building Information Modeling (BIM) to the Construction Industry: A Review
}

\author{
Shakil Ahmed \\ Department of Building Engineering and Construction Management, Khulna University of \\ Engineering and Technology (KUET), Khulna, Bangladesh \\ E-mail: ashakilmondol@gmail.com
}

\begin{abstract}
Construction industry is one of the largest economic sector in the world in 2017. And Building Information Modeling (BIM) is the powerful set of technology to design, construction and management has been strengthen the construction industry. BIM has significant benefits for the project lifecycle even after it's lifecycle but this benefits can't gain by the project because of failure to successful implementation of BIM technology to the construction industry. The main objectives of this study is to identify the most crucial barrier to implementation of BIM and develop a relative rank with their relative impact on this issue. The study was conducted by a comprehensive literature review and necessary data was collected by literature review also. A set of barrier was developed by the literature review containing 37 barrier which curb the implementation of BIM technology to the construction sector. Relative rank based on their frequency and relative impact was calculate for each barrier identified in the literature review. The five most crucial barrier to the implementation of BIM are B17 (Social and habitual resistance to change), B19 (Traditional methods of contracting), B3 (Training expenses and the learning curve are too expensive), B20 (High cost of software purchasing) and B33 (Lack of awareness about BIM). And the five most impactful barrier are B19 (Traditional methods of contracting), B17 (Social and habitual resistance to change), B33 (Lack of awareness about BIM), B2 (Unavailability of proper training on BIM) and B28 (Lack of BIM experts). To gain the tremendous benefits of BIM technology, it is necessary to overcome the barrier based on priority with the help of government and all the stakeholder of project.
\end{abstract}

Key Words: BIM; Barrier; Literature Review; Relative Impact; Construction Industry

\section{Introduction}

According to Autodesk, the developer of various Building Information Modeling (BIM) tools "BIM (Building Information Modeling) is an intelligent 3D model-based process that gives architecture, engineering, and construction (AEC) professionals the insight and tools to more efficiently plan, design, construct, and manage buildings and infrastructure" [1]. Another definition is "a digital representation of physical and functional characteristics of a facility. As such it serves as a shared knowledge resource for information about a facility forming a reliable basis for decisions during its life-cycle from inception onward" [2]. BIM is a significant technological advancement of the construction industry for drawing, modeling, simulation, management and control. It has been becoming the most essential part of entire Architecture, engineering and construction (AEC) industries in the world. The concept of BIM originated for the simple computing applications at 1960s and improved for solid modeling programs at 1970s [3]. A source state that development of ArchiCAD software is considered as the true evaluation of BIM and application of Revit software is the effective implementation of modern advance BIM [4]. The major idea of BIM is to completion of a project virtually before the project construction started physically to find out potential risk, problems and conflicts. It also analyzed the techniques and process of construction, viability of socio-economic factors during the early design phase of project. BIM means the effective and efficient organizing systems of collaboration of appropriate personnel and information which planned for different predefined process and technology rather than application of CAD and 3D modeling. BIM is a data based, object-oriented, intelligent and virtual presentation of facility that help to make decision and improve the process of construct and delivery [5]. The key factors of BIM is personnel, process, information and technology [6].

A Building Information Modeling (BIM) in the building construction case is a 3D modeling which deals with design, planning, construction and operation [7]. The 3D model contain with rich data about structural, technical and management. And used to analysis of building performance, sustainability, schedules and cost issues [8]. At the early age, Building information modeling (BIM) is used to design and analysis of different stage of building construction but now it is used to monitor, control and manage the operation and maintain of building and performance and also used in production and services industries. BIM is developed an advanced and appropriate set of techniques and process involve in project whole lifecycle [9]. 
Building Information Modeling (BIM) redefined the architecture, engineering, and construction (AEC) industry from the very late of twenty centuries. The modern concept of BIM developed with the idea of 3D modeling of project later expanded the concept to 4D associated with the construction processing and scheduling, 5D modelling with cost estimation of project, 6D modelling with sustainability of project, 7D modelling with facilities management and application and even nD modelling [10]. It's miles broadly believed that BIM can play a widespread position in integrating the various phases all through the entire lifecycle of a production project [11]. To overcome the low productivity of construction project and other risk and barriers which affect the improvement of construction industry, BIM strangely implemented at AEC industry at early 1990s [12]. BIM technology gives a range of direct and indirect benefits and makes the whole design and construction process more simplified and transparent in many aspects [13].

About $40 \%$ unbudgeted cost are reducing with the help of BIM technologies and reduce the time to project delivery to the client without any major conflict by $7 \%$ and approximately $80 \%$ contraction in the time it takes to bring about cost estimates with a higher rate of accuracy around 3\% [5]. Construction Industry Institute estimated in 2004 that $57 \%$ of money spent on construction is non-value added which is waste with the U.S. construction market estimated at US\$1.288 trillion for 2008, at 57\% waste, over \$600 billion per year is being wasted [14]. BIM aid the UK Government in saving approximately $\$ 1.7$ billion in construction costs in 20132014, creating the road for the Digital Built Britain policy for construction and procurement which is fully BIMdriven in the UK [15]. The BIM technology can integrate design, construction, maintenance and control. It is a rich model with sufficient data for the lifecycle and assist all stakeholders with improvements in performance efficiency. BIM is the best technology for the sustainable design and development by reducing of costs, risk and waste as well carbon emissions and environmental pollutions. BIM technology also results in hard work marketplace enhancements, strengthen greater collaborative working practices, and improves communication between project stakeholders [16].

The objectives of this study is to identify the critical barrier to implementation of BIM technology to the construction industry by conducting a comprehensive literature review. And also identify the relative impact of each barrier to implementation to the industry.

\section{Methodology}

The critical factors that affect the implementation of BIM and the benefits of implementation of BIM are questionnaire design for the study by conducting a comprehensive literature review. The questionnaire design finalized from an intensive review of journal paper, research paper, technical and review paper, books, articles and websites and blogs. Then a relative ranking and impact is found among the barrier to implementation of BIM technology to the construction industry based on the frequency on literatures. Then the relative impact of each barrier calculate from the equation (1);

$$
\text { Relative Impact, } \mathrm{RI}=\frac{F}{H X A X P}
$$

In equation (1), $\mathrm{F}$ is the frequency of the barrier, $\mathrm{P}$ is the highest rank found from literature review of the barrier, $\mathrm{A}$ is the lowest rank found from literature review of the barrier and $\mathrm{H}$ is the highest frequency among all barrier ( $\mathrm{H}=28$ for this study).

\section{Result and Discussions}

The study identify the main critical barrier to the implementation of Building Information Modeling (BIM) to the construction industry. Table 1 shows the relative rank among the critical factors that affect the successful implementation of BIM technology in construction industry based on the existing frequency on reviewing literature materials. Figure 1 also represent frequency against the barriers graphically. The top twelve factors affecting the implementation of BIM technology to the construction sector are (1) Social and habitual resistance to change ( $\mathrm{F}=28)$, (2) Traditional methods of contracting ( $\mathrm{F}=28)$, (3) Training expenses and the learning curve are too expensive $(\mathrm{F}=27)$, (4) High cost of software purchasing $(\mathrm{F}=26)$, (5) Lack of awareness about BIM $(\mathrm{F}=26),(6)$ High cost of BIM hardware and tools $(\mathrm{F}=25)$, (7) Initial set up of BIM is difficult $(\mathrm{F}=24)$, (8) Lack of BIM experts $(\mathrm{F}=24)$, (9) High Maintenance costs $(\mathrm{F}=24)$, (10) unavailability of proper training on BIM ( $\mathrm{F}=23)$, (11) Complexity of BIM ( $\mathrm{F}=23)$ and (12) BIM licensing problems ( $\mathrm{F}=23)$. And the lowest impactful factors that affect the implementation of BIM are (1) Unavailability of BIM risk insurances (F=5), (2) Poor Internet Connectivity $(\mathrm{F}=6)$, (3) Frequent Power Failure ( $\mathrm{F}=6)$, (4) Construction market is not suitable and ready yet $(\mathrm{F}=7)$. 
Table 1: Rank of barriers to the implementation of BIM

\begin{tabular}{|c|c|c|c|c|}
\hline ID & Barrier & Frequency $\mathbf{F}$ & Rank & $\begin{array}{l}\text { Relative } \\
\text { Impact }\end{array}$ \\
\hline B1 & Construction market is not suitable and ready yet & 7 & 34 & 0.0317 \\
\hline B2 & Unavailability of proper training on BIM & 23 & 9 & 0.0730 \\
\hline B3 & $\begin{array}{l}\text { Training expenses and the learning curve are too } \\
\text { expensive }\end{array}$ & 27 & 2 & 0.0667 \\
\hline B4 & $\begin{array}{l}\text { Higher authority and decision maker don't provide full } \\
\text { support }\end{array}$ & 16 & 21 & 0.0635 \\
\hline B5 & Unavailability of BIM risk insurances & 5 & 37 & 0.0159 \\
\hline B6 & $\begin{array}{l}\text { The system of single-discipline design but not integrated } \\
\text { design }\end{array}$ & 12 & 28 & 0.0476 \\
\hline B7 & Benefits are not tangible enough to warrant its use & 21 & 15 & 0.0567 \\
\hline B8 & $\begin{array}{l}\text { Contractor don't usually prove empirically the benefits of } \\
\text { BIM to clients }\end{array}$ & 22 & 13 & 0.0492 \\
\hline B9 & $\begin{array}{l}\text { Difficult to having everyone on project to make BIM } \\
\text { effort worthwhile }\end{array}$ & 15 & 25 & 0.0317 \\
\hline B10 & Too many legal barriers exit & 17 & 19 & 0.0397 \\
\hline B11 & The legal barriers overcome cost & 9 & 32 & 0.0317 \\
\hline B12 & Lack of global use in local construction industry & 18 & 17 & 0.0643 \\
\hline B13 & $\begin{array}{c}\text { Not sufficient demand from clients and/or other } \\
\text { organizations on projects }\end{array}$ & 20 & 16 & 0.0714 \\
\hline B14 & $\begin{array}{l}\text { lack of guidelines and standards of the way BIM have to } \\
\text { be implemented for construction industry }\end{array}$ & 16 & 21 & 0.0794 \\
\hline B15 & Uncertainty of the benefits of BIM implementation & 10 & 31 & 0.0556 \\
\hline B16 & Current technology in construction is enough & 9 & 32 & 0.0635 \\
\hline B17 & Social and habitual resistance to change & 28 & 1 & 0.0833 \\
\hline B18 & Complexity of BIM & 23 & 9 & 0.0563 \\
\hline B19 & Traditional methods of contracting & 28 & 1 & 0.0817 \\
\hline B20 & High cost of software purchasing & 26 & 4 & 0.0643 \\
\hline B21 & High cost of BIM hardware and tools & 25 & 5 & 0.0587 \\
\hline B22 & BIM licensing problems & 23 & 9 & 0.0317 \\
\hline B23 & High Maintenance costs & 24 & 7 & 0.0508 \\
\hline B24 & $\begin{array}{l}\text { Low computer skills among a lot of participants in the } \\
\text { construction industry }\end{array}$ & 22 & 13 & 0.0492 \\
\hline B25 & Requirement of advanced electronics equipment & 13 & 26 & 0.0476 \\
\hline B26 & $\begin{array}{l}\text { The shortage of sufficient time to evaluate BIM and its } \\
\text { training }\end{array}$ & 16 & 21 & 0.0159 \\
\hline B27 & Absence or incomplete national standard for BIM & 18 & 17 & 0.0556 \\
\hline B28 & Lack of BIM experts & 24 & 7 & 0.0722 \\
\hline B29 & Lack of information sharing in BIM & 12 & 28 & 0.0794 \\
\hline B30 & Firms are not familiar enough with BIM use & 16 & 21 & 0.0556 \\
\hline B31 & $\begin{array}{l}\text { It does not help if your counter-parties are not using the } \\
\text { BIM }\end{array}$ & 11 & 30 & 0.0397 \\
\hline
\end{tabular}




$\begin{array}{lcccc}\text { B32 } & \text { Initial set up of BIM is difficult } & 24 & 7 & 0.0579 \\ \text { B33 } & \text { Lack of awareness about BIM } & 26 & 4 & 0.0802 \\ \text { B34 } & \text { People comparing BIM to CAD } & 13 & 26 & 0.0397 \\ \text { B35 } & \text { Poor internet connectivity } & 6 & 36 & 0.0238 \\ \text { B36 } & \text { Frequent power failure } & 6 & 35 & 0.0159 \\ \text { B37 } & \text { Product liability risks } & 17 & 19 & 0.0079\end{array}$

Source: [1-39]

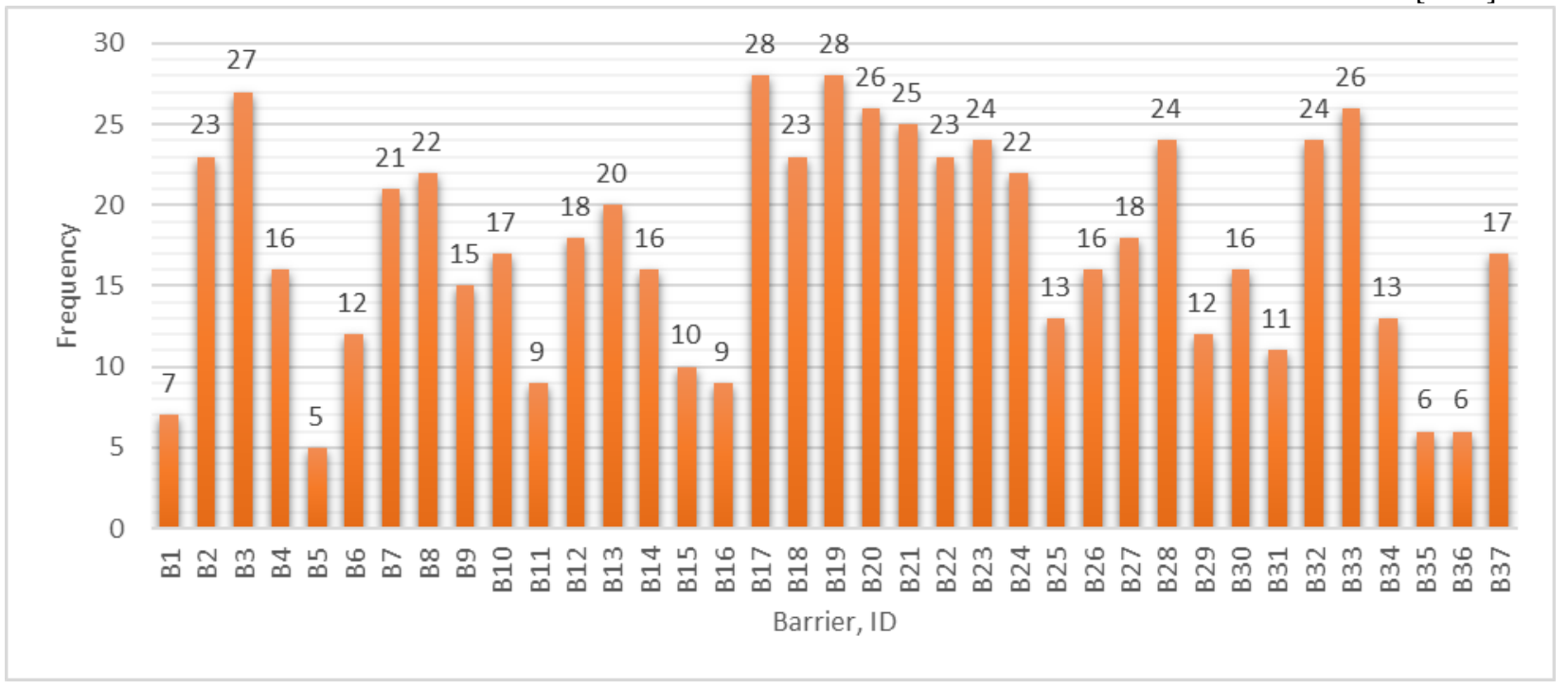

Figure 1: Frequency against the each barrier to implementation of BIM

The social and habitual resistance to change is a very natural factor within every living being. The uncertainty of changing try to remain everyone to unchanged like the involved stakeholders in construction project. The second most significant factor is traditional method of contracting. The involve parties are familiar and adapted with the traditional method for a long time and they are expert and quick with this traditional method. So replace these method is not easy to stakeholders and also not acceptable for everyone. Some people have low selfconfidence especially related with implementing new technology because the lack of knowledge [40]. Training expenses and the learning curve are too expensive for the successful implementation of BIM technology to the construction industry. For this reason the local construction firms are not interest to adopt the BIM technology for the issue of huge capital investment. The high cost of software value for initiation of BIM is another top barrier to implementation of BIM. The lack of awareness about BIM is strengthened the system of failure of implementation of BIM technology to the construction industry. Without significant knowledge and awareness about BIM each parties of the construction project is reluctant to the adoption of BIM.

On the other hand, the less impactful factors that affect the successful implementation of BIM technology to the construction industry are not as responsible as the top factors are. Unavailability of BIM risk insurances is the top less important factor that affect the implementation of BIM. Lack of knowledge about BIM of the insurance company, they don't provide sufficient insurance for BIM technology. The sufficient internet connection and frequent power failure also have some impact to resisting the implementation of BIM. Without internet and power BIM technology can't implement and run with progressive ways, causes most of the BIM tools are continuous power and internet based.

For the overcome of the barrier to implementation of BIM technology to the construction industry it is important to prioritize the barrier according to the impact value. Figure 2 shows the impact of each barrier perfectly with their frequency. Those barriers should try to solve first which have the greater impact on implementing BIM technology. In this study B19 (traditional methods of contracting), B17 (social and habitual resistance to change), B33 (Lack of awareness about BIM), B2 (unavailability of proper training on BIM) and B28 (lack of BIM experts) are the high ranked high impactful barriers to the implementation of BIM. To overcome this issue these high ranked high impactful barriers is the key barrier to solve first. The low ranked low impactful barriers come to last to solve them to overcoming the BIM implementation problem in construction industry. Such low ranked low impactful barriers are find in this study are B37 (Product liability 
risks), B5 (Unavailability of BIM risk insurances), B36 (Frequent Power Failure) and B35 (poor internet connectivity).

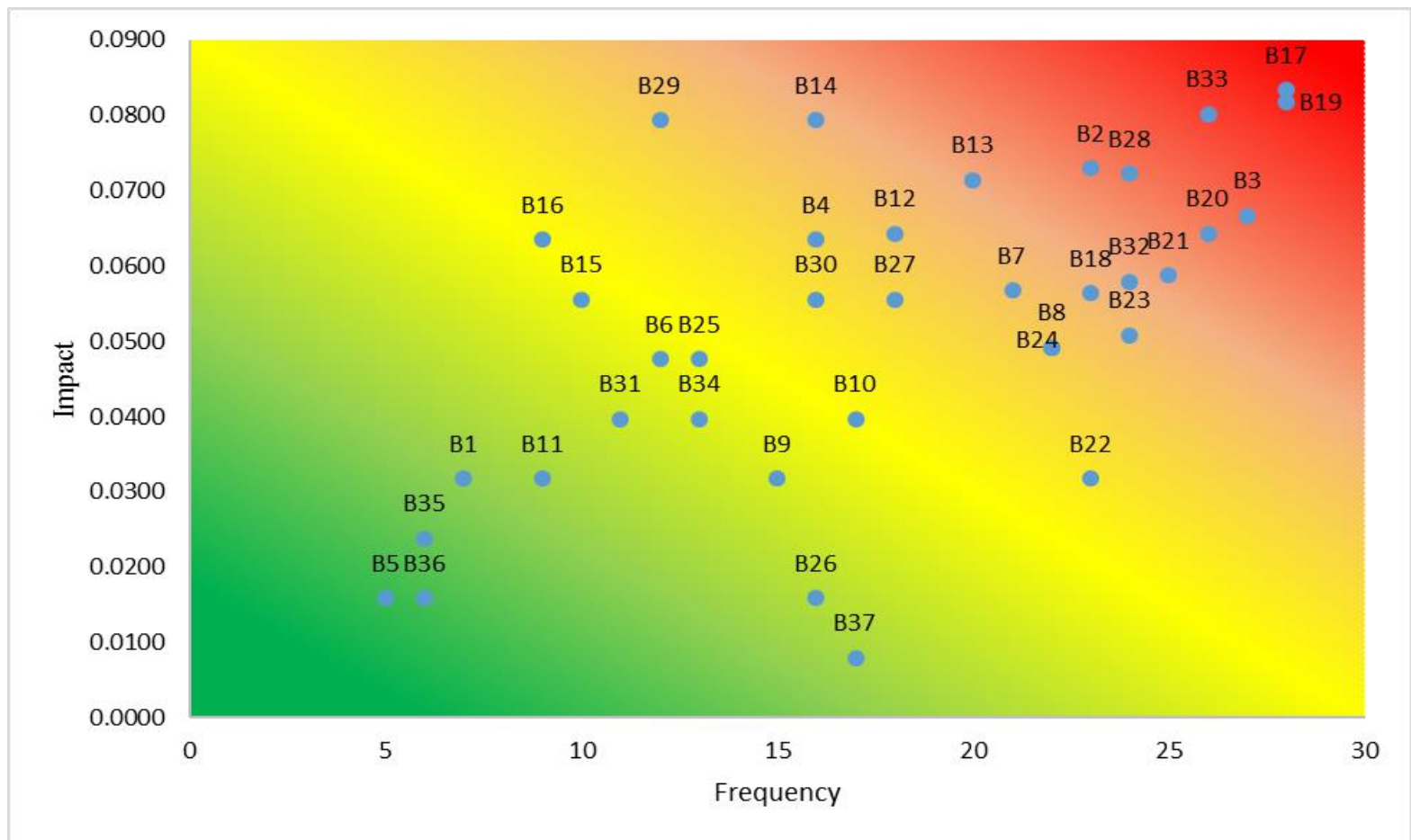

Figure 2: Impact matrix of barrier of implementation of BIM

\section{Conclusion}

Enough evidence proved that building information Modelling (BIM) can promote the construction performance however the rate of implementation of BIM within the construction industry has been at a slow tempo. A good number of factors that contribute this issue are identified in this study such as (1) Social and habitual resistance to change, (2) Traditional methods of contracting, (3) Training expenses and the learning curve are too expensive, (4) High cost of software purchasing and (5) Lack of awareness about BIM. These problems need to be addressed hence if the government wants to see the construction industry capable of compete globally. Besides that, supports from the government also play a tremendous role to increase the rate of BIM implementation in the construction sector. Countries like the United Kingdom (UK), Australia, Hong Kong and Singapore have implemented the use of BIM in their construction industry through their governments [39]. In the United Kingdom for instance, the authorities is mandating BIM; Australia is assisting BIM, Singapore enforces the usage of BIM as part of their policy and terms of contract and Hong Kong is supporting BIM [4143]. By means of just having a solid support from the government alone isn't effective; therefore, the construction stakeholders including owner, consultants and contractors should play their very own role by transferring the paradigm from using the traditional method right into a greater innovative method. It can be concluded that the construction industry over the barrier to implementing BIM by the progressive participation of government authorities, all stakeholders of construction.

\section{References}

[1] Autodesk, BIM and the future of AEC, 2017. https://www.autodesk.com/solutions/bim. (Accessed 08/11/2017 2017).

[2] NIBS, National BIM Standard-United States, National Institute of Buildiing Sciences, United State of America, 2015.

[3] P. Smith, BIM implementation-global strategies, Procedia Engineering 85 (2014) 482-492.

[4] V. Quirk, A Brief History of BIM/Michael S. Bergin, Architecture News (2012).

[5] S. Azhar, Building information modeling (BIM): Trends, benefits, risks, and challenges for the AEC industry, Leadership and management in engineering 11(3) (2011) 241-252. 
[6] Y. Arayici, C. Egbu, S. Coates, Building information modelling (BIM) implementation and remote construction projects: issues, challenges, and critiques, Journal of Information Technology in Construction 17 (2012) 75-92.

[7] W. Kymmell, Building Information Modeling: Planning and Managing Construction Projects with 4D CAD and Simulations (McGraw-Hill Construction Series): Planning and Managing Construction Projects with 4D CAD and Simulations, McGraw Hill Professional2007.

[8] M.M. Uddin, A.R. Khanzode, Examples of How Building Information Modeling can enhance career paths in construction, Practice Periodical on Structural Design and Construction 19(1) (2013) 95-102.

[9] P. Demian, D. Walters, The advantages of information management through building information modelling, Construction Management and Economics 32(12) (2014) 1153-1165.

[10] A. Mohanta, S. Das, BIM as facilities management tool a brief review, (2017).

[11] Y. Jung, M. Joo, Building information modelling (BIM) framework for practical implementation, Automation in Construction 20(2) (2011) 126-133.

[12] P. Teicholz, Labor productivity declines in the construction industry: causes and remedies, AECbytes Viewpoint 4(14) (2004) 2004.

[13] G. Lee, H.K. Park, J. Won, D 3 City project-Economic impact of BIM-assisted design validation, Automation in Construction 22 (2012) 577-586.

[14] B. AL-OTAIBI, CHALLENGES AND SETBACKS IN THE IMPLEMENTATION OF BUILDING INFORMATION MODELLING (BIM): A CASE STUDY, WIT Transactions on The Built Environment 169 (2017) 15-23.

[15] B. Blackwell, Industrial strategy: government and industry in partnership, Building Information Modelling (2015).

[16] A. Porwal, K.N. Hewage, Building Information Modeling (BIM) partnering framework for public construction projects, Automation in Construction 31 (2013) 204-214.

[17] M. Abubakar, Y. Ibrahim, D. Kado, K. Bala, Contractors' Perception of the Factors Affecting Building Information Modelling (BIM) Adoption in the Nigerian Construction Industry, Computing in Civil and Building Engineering (2014)2014, pp. 167-178.

[18] M.A.K. AL-Btoush, A.T. Haron, Global Journal of Engineering Science and Research Management.

[19] Y. Arayici, F. Khosrowshahi, A.M. Ponting, S. Mihindu, Towards implementation of building information modelling in the construction industry, (2009).

[20] S. Azhar, W.A. Carlton, D. Olsen, I. Ahmad, Building information modeling for sustainable design and LEED® rating analysis, Automation in construction 20(2) (2011) 217-224.

[21] A. Banawi, Barriers to Implement Building Information Modeling (BIM) in Public Projects in Saudi Arabia, International Conference on Applied Human Factors and Ergonomics, Springer, 2017, pp. 119-125.

[22] D. Cao, H. Li, G. Wang, T. Huang, Identifying and contextualising the motivations for BIM implementation in construction projects: An empirical study in China, International journal of project management 35(4) (2017) 658-669.

[23] C.T. Chan, Barriers of implementing BIM in construction industry from the designers' perspective: a Hong Kong experience, Journal of System and Management Sciences 4(2) (2014) 24-40.

[24] P. Diaz, Analysis of Benefits, Advantages and Challenges of Building Information Modelling in Construction Industry, Journal of Advances in Civil Engineering 2(2) (2016) 1-11.

[25] R. Eadie, H. Odeyinka, M. Browne, C. McKeown, M. Yohanis, Building information modelling adoption: an analysis of the barriers to implementation, Journal of Engineering and Architecture 2(1) (2014) 77-101.

[26] A. Elmualim, J. Gilder, BIM: innovation in design management, influence and challenges of implementation, Architectural Engineering and design management 10(3-4) (2014) 183-199.

[27] A. Enshassi, L. AbuHamra, S. Mohamed, BARRIERS TO IMPLEMENTATION OF BUILDING INFORMATION MODELLING (BIM) IN THE PALESTINIAN CONSTRUCTION INDUSTRY, International Journal of Construction Project Management 8(2) (2016) 103.

[28] M. Gerges, S. Austin, M. Mayouf, O. Ahiakwo, M. Jaeger, A. Saad, T.-E. Gohary, An investigation into the implementation of Building Information Modeling in the Middle East, Journal of Information Technology in Construction (ITcon) 22(1) (2017) 1-15.

[29] J. Jupp, Incomplete BIM implementation: Exploring challenges and the role of product lifecycle management functions, 10th Product Lifecycle Management for Society (PLM), Springer, 2013, pp. 630-640.

[30] S. Liu, B. Xie, L. Tivendal, C. Liu, Critical barriers to BIM implementation in the AEC industry, International Journal of Marketing Studies 7(6) (2015) 162.

[31] R.T. Manning, Challenges, Benefits, \& Risks Associated with Integrated Project Delivery and Building Information Modeling, (2012).

[32] R. Matarneh, S. Hamed, Barriers to the Adoption of Building Information Modeling in the Jordanian Building Industry, Open Journal of Civil Engineering 7(03) (2017) 325. 
[33] C. Morrison, BIM 2010: The benefits and barriers for construction contractors in Auckland, (2010).

[34] R. Padmini, Scope of Implementing Building Information Modeling In Architecture Engineering Construction (AEC) Firms of India, Proceedings of 2016 2nd International Conference on Architecture, Structure and Civil Engineering, London (UK), 2016.

[35] A.Q. Sahil, Adoption of building information modeling in developing countries: A phenomenological perspective, Colorado State University, 2016.

[36] R.A. Stewart, S. Mohamed, M. Marosszeky, An empirical investigation into the link between information technology implementation barriers and coping strategies in the Australian construction industry, Construction Innovation 4(3) (2004) 155-171.

[37] E.A.L. Teo, G. Ofori, I.K. Tjandra, H. Kim, The potential of Building Information Modelling (BIM) for improving productivity in Singapore construction, THIRTY-FIRST ANNUAL CONFERENCE 2015 September 7-9, 2015, p. 661.

[38] H. Yan, P. Demian, Benefits and Barriers of Building Information Modelling Available: http://www. staff. lboro. ac. uk/ cvpd2, PDFs/294_Benefits\% 20and\% 20Barriers\% 20of 20 (2008).

[39] A.H. Zuhairi, A. Marshall-Ponting, T.H. Ahmad, M.A. Nasly, Z. Zahrizan, Exploring the barriers and driving factors in implementing building Information Modelling (BIM) in the malaysian construction industry-a preliminary study, (2014).

[40] W.J. O'Brien, Implementation issues in project web sites: a practioner's viewpoint, Journal of management in engineering 16(3) (2000) 34-39.

[41] L. Khemlani, CORENET e-PlanCheck: Singapore's automated code checking system, AECbytes, October (2005).

[42] B. Succar, Building information modelling framework: A research and delivery foundation for industry stakeholders, Automation in construction 18(3) (2009) 357-375.

[43] T.A. Lin, C.T. FATT, Building smart-a strategy for implementing BIM solution in Singapore, Synthesis Journal. Singapore (2006) 117-124. 